DOI: $10.17951 / 1 r p .2020 .40 .1 .87-100$

\title{
KATARZYNA BŁAŻEJEWSKA
}

Uniwersytet Kardynała Stefana Wyszyńskiego w Warszawie

ORCID - 0000-0003-2793-3276

\section{PRACA DOMOWA W OPINII UCZNIÓW KLAS I-III I ICH RODZICÓW}

\begin{abstract}
Streszczenie: Wprowadzenie: Artykuł traktuje o pracy domowej uczniów w edukacji wczesnoszkolnej. Cel i metoda badań: Dokonano przeglądu literatury pedagogicznej dotyczącej pracy domowej oraz przeprowadzono badania wśród 84 uczniów klas I-III i ich rodziców, koncentrując się na opinii respondentów dotyczącej potrzeby zadawania pracy domowej, a w szczególności: deklarowanej częstotliwości zadawania prac domowych, rodzajów prac domowych, stosunku uczniów do ich odrabiania oraz ilości czasu poświęconego na ich wykonanie. Zastosowano metodę sondażu diagnostycznego z wykorzystaniem techniki ankiety. Wyniki: Spośród wszystkich badanych uczniów 98,8\% deklaruje, że ma zadawaną pracę domową. Wśród zadawanych prac dominują wybrane zagadnienia z podręcznika lub ćwiczeń, prace pisemne w zeszycie, tekst do przeczytania, karty pracy, nauka wiersza na pamięć, doświadczenia, kolorowanki, przygotowanie informacji na określony temat. Najczęstszym powodem sprzeciwu rodziców i dzieci wobec zadawania prac domowych jest czas, jaki uczniowie poświęcają na jej wykonanie. Badani wskazali na potrzebę zadawania prac domowych głównie ze względu na konieczność utrwalenia materiału oraz doskonalenia umiejętności. Wnioski: Przeprowadzone badania wskazują na potrzebę zadawania prac domowych głównie ze względu na konieczność utrwalania wiedzy zdobytej w szkole i doskonalenia umiejętności uczniów.
\end{abstract}

Słowa kluczowe: edukacja wczesnoszkolna, praca domowa, rodzice, uczniowie klas I-III

\section{WPROWADZENIE}

Obecnie coraz częściej poruszany jest temat potrzeby i roli zadawanej uczniom pracy domowej. Do toczącego się sporu między uczniami i ich rodzicami a nauczycielami został nawet włączony Rzecznik Praw Obywatelskich oraz Rzecznik Praw Dziecka. Z informacji prasowych wynika, że coraz więcej osób jest przeciwnych 
zadawaniu dzieciom pracy do domu, wręcz cały proceder jest nazywany, w ekstremalnych przypadkach, ograniczaniem swobód obywatelskich dziecka. Rodzice uważają, że ich prawa rodzicielskie są również w ten sposób ograniczane - nie mają możliwości spędzania czasu ze swoimi dziećmi w sposób inny niż odrabianie pracy domowej. Ta postawa rodziców jest częściowo, jak sądzę, pokłosiem nowej publikacji amerykańskiego psychologa Alphiego Kohna pt. Mit pracy domowej, stojącej w opozycji do wcześniejszych opracowań traktujących pracę domową jako niezbędny „składnik tradycyjnego systemu szkolnego” (Okoń, 2003, s. 303).

\section{PRACA DOMOWA - RAMY POJĘCIOWE}

W literaturze klasycznej mianem dobrej pracy domowej jest określana praca zaplanowana i zgodna z tematem lekcji (Kołodziej, Niesporek-Szamburska, 2009), która służy zrozumieniu materiału, utrwaleniu wiedzy, szczególnie takiej, którą uczniowie będą umieli wykorzystać w różnych sytuacjach i dzięki której będą umieli rozwiązywać różnorakie problemy (Kupisiewicz, 1980; Więckowski, 1983; Kozak 1984; Okoń, 2007). Powinna być zindywidualizowana (Kupisiewicz, 1980; Więckowski, 1983; Kołodziej, Niesporek-Szamburska, 2009), łączyć różne zadania pozwalające na własną inicjatywę, umożliwiające poszukiwanie nowych sposobów rozwiązywania problemów (Kołodziej, Niesporek-Szamburska, 2009) i rozwijające zdolności twórcze (Zborowski, 1955). Powinna sprzyjać samodzielnemu, krytycznemu myśleniu, kształtować umiejętność uczenia się (Miodek, 1988; Reclik, 2005; Bałachowicz, 2006; Dudel, 2007), uczyć odpowiedzialności, samokontroli i samooceny (Reclik, 2005) oraz systematyczności (Zborowski, 1955).

Przeprowadzone za granicą, w ostatnich latach, badania wykazały, że w szkole podstawowej praca domowa nie wpływa na postępy w nauce. Autorzy powołujący się na te badania sugerują zmianę podejścia do zadawanej uczniom pracy domowej (Juul, 2014; Hattie, 2015; Kohn, 2018).

\section{ROLA RODZICÓW}

W procesie edukacji, obok nauczycieli i uczniów, ważną grupę stanowią rodzice uczniów. W literaturze przedmiotu często porusza się kwestię konieczności ich współpracy z nauczycielami. W praktyce zapomina się, że najważniejszy jest uczeń, a celem wspólnych działań i rodziców, i nauczycieli powinno być podnoszenie jakości kształcenia. Należy pamiętać o współuczestnictwie tych stron w działalności edukacyjnej oraz podtrzymywaniu dialogu między nimi (Lulek, 2017). 
Ważne, by rodzice mieli świadomość, jaką rolę odgrywa zadana dzieciom praca domowa. Powinni zorganizować dziecku warunki do pracy - odpowiednie miejsce w domu (biurko, oświetlenie) oraz czas (najlepiej o stałej porze, ok. dwie godziny po powrocie ze szkoły, a nie w późnych godzinach wieczornych). Ogromny wpływ na uczenie się przez dziecko samodzielności ma atmosfera (powaga, niezakłócanie ciszy) i zainteresowanie rodziców nauką. Według badań prowadzonych w 2004 roku (Winiarczyk, 2007-2008) rodzice uważają, że ich pomoc w odrabianiu lekcji jest niezbędna głównie ze względu na niedostateczne wytłumaczenie pracy domowej przez nauczyciela. Konieczne jest uświadomienie rodzicom, że powinni naprowadzać, zadawać pytania pomocnicze, a nie wykonywać zadania za dzieci. Zdarza się niestety, że to rodzice piszą w zeszytach dzieci, nie zdając sobie sprawy, że bardziej im szkodzą, niż pomagają. Rodzice powinni interesować się zarówno sukcesami, jak i porażkami swoich pociech. Dzieci podtrzymują zapał do nauki, uczą się obowiązkowości i pilności dzięki zainteresowaniu rodziców. W obecnych czasach, gdy rodzice są zajęci głównie własnymi sprawami - często tylko dzięki pracy domowej i poświęceniu jej uwagi rodzice wiedzą, co dzieje się na lekcjach w szkole dzieci, czego obecnie się uczą. Czytając wypowiedzi rodziców, niechętnie patrzących na zadawanie pracy domowej swoim dzieciom, można zauważyć, że najczęściej podają argumenty antypatii uczniów wobec pracy domowej. I rzeczywiście, dawno już potwierdzono, że najbardziej skuteczna jest nauka dobrowolna, oparta na wewnętrznej motywacji, gdy dzieci są nią autentycznie zainteresowane (Dudel, 2007), a nie wtedy, gdy spotyka je kara za niewykonanie zadań.

\section{PROBLEM I CEL BADAŃ}

Badanie miało na celu poznanie opinii uczniów klas I-III szkoły podstawowej i ich rodziców, dotyczącej pracy domowej. W szczególności starano się uzyskać odpowiedzi na kwestie dotyczące:

1) deklarowanej częstotliwości zadawania prac domowych w poszczególnych klasach,

2) rodzaju zadawanych prac domowych,

3) stosunku uczniów do odrabiana prac domowych,

4) czasu poświęconego na odrabianie prac domowych.

\section{METODA BADAŃ I CHARAKTERYSTYKA PRÓBY}

W badaniu wzięło udział 84 uczniów z 38 placówek i 84 rodziców. Badania prowadzono na terenie województwa mazowieckiego. Spośród badanych uczniów 
72 uczęszcza do szkoły w Warszawie, 12 do szkół w podwarszawskich miejscowościach. W ankiecie wzięło udział 29 uczniów klas pierwszych, 38 klas drugich i 17 uczniów klas trzecich.

Zastosowano metodę sondażu diagnostycznego z wykorzystaniem techniki ankiety (z dysjunktywnymi, półotwartymi i koniunktywnymi kafeteriami oraz pytaniami otwartymi). Badano częstotliwość i rodzaj zadawanych przez nauczycieli prac domowych, ilość czasu spędzanego przy odrabianiu pracy domowej, potrzebę pomocy rodziców w jej odrabianiu oraz stosunek uczniów i ich rodziców do pracy domowej.

\section{PROCEDURA ANALIZY DANYCH}

Dane zostały uzyskane na podstawie wypełnionych przez respondentów kwestionariuszy ankiet. Ze względu na trudną sytuację, wynikającą z pandemii, 29 uczniów wypełniło ankietę pisemnie, pozostałych 55 badanych wypełniało ankietę online. W przypadku rodziców zebrano 36 ankiet wypełnionych na papierze, pozostałe 48 zostało wypełnionych online. Zebrane dane zostały zestawione ze sobą i przeanalizowane przez autora pod kątem przedstawienia opinii uczniów klas I-III szkoły podstawowej i ich rodziców, dotyczącej pracy domowej.

\section{WYNIKI BADAŃ}

Według 35,7\% uczniów nauczyciel zadaje pracę domową codziennie, z czego uczniowie klas pierwszych stanowią 30\% tej grupy, klas drugich - 40\%, klas 3 także 30\%. Prawie 37\% uczniów ma zadawaną pracę co 2-3 dni (uczniowie I klasy stanowią 16\%, II klasy - 64,5\%, III klasy - 19,3\%); 20\% uczniów raz na tydzień (uczniowie klasy I stanowią 65\%, klasy II - 17,6\%, III klasy - 5,8\%); 5,9\% uczniów odrabia pracę domową rzadziej niż raz w tygodniu (uczniowie I klasy stanowią 20\% tej grupy, II klasy - 60\%, III klasy - 20\%). Tylko 1,2\% badanych zadeklarowało, że nauczyciel nie zadaje prac domowych (klasa I). Oznacza to, że 92,7\% badanych przynajmniej raz w tygodniu ma zadawaną pracę domową. Spośród badanych rodziców 42,8\% stwierdziło, że nauczyciele zadają pracę domową codziennie (klasa I stanowi 16,6\% tej grupy, klasa II - 47,2\%, a klasa III - 36,1\%); $36,9 \%$ co 2-3 dni (klasa I stanowi 54,8\%, klasa II - 35,4\%, a III klasa - 9,6\%); 14,2\% raz $\mathrm{w}$ tygodniu (66\% tej grupy stanowią uczniowie klasy I, a 33\% uczniowie klasy II); a 5,9\% rzadziej niż raz w tygodniu (20\% tej grupy są uczniowie klasy I, $80 \%$ klasy II). W klasie III najczęściej praca domowa jest zadawana codziennie $(81,2 \%)$, 
tak samo jak w II klasie (47,2\%). W klasie I nauczyciele najczęściej zadają pracę domową co $2-3$ dni $(53,1 \%)$.

Odpowiedzi rodziców i dzieci w znacznej części pokrywają się, co przedstawia poniższy wykres.

Wykres 1 .

Częstotliwość zadawania prac domowych przez nauczycieli

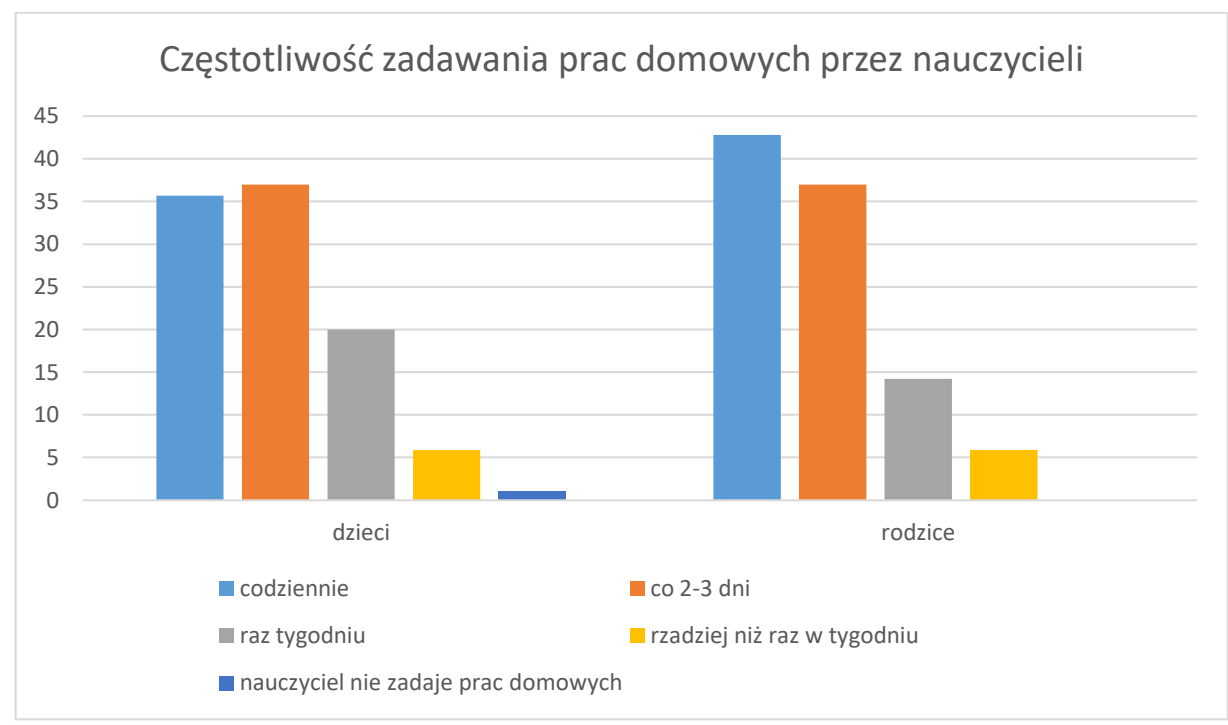

Wśród zadawanych prac, według uczniów, dominują wybrane zagadnienia z podręcznika lub ćwiczeń $(84,5 \%)$, prace pisemne w zeszycie $(72,6 \%)$, tekst do przeczytania (63\%), karty pracy (57,1\%), nauka wiersza na pamięć (19\%), doświadczenia (17,8\%), kolorowanki (16,6\%), przygotowanie informacji na określony temat $(15,4 \%)$. Gry stanowią $2,4 \%$ prac domowych, lapbook - 1,2\%. W klasie pierwszej wybrane zagadnienia z podręcznika lub ćwiczeń stanowią $86 \%$ prac domowych, prace pisemne w zeszycie - 75,8\%, karty pracy - 72,4\%, tekst do przeczytania tylko $55 \%$, nauka wiersza na pamięć - 27,5\%, a gry i wykonanie doświadczeń po $3,4 \%$. Nieco inaczej wygląda to w klasie drugiej. Co prawda przeważają zagadnienia z podręcznika lub ćwiczeń $(94,7 \%)$ i prace pisemne w zeszycie $(65,7 \%)$, ale częściej zadawany jest tekst do przeczytania $(60,5 \%)$, rzadziej natomiast karty pracy $(55,2 \%)$. Wśród prac domowych 28,9\% stanowią doświadczenia, 26,3\% kolorowanki, 23,6\% przygotowanie informacji na określony temat, $21 \%$ nauka wiersza na pamięć. Tylko 5,2\% prac stanowi gra $(2,6 \%)$ lub lapbook $(2,6 \%)$. W klasie trzeciej również 
przeważają zadania zamieszczone w podręczniku lub ćwiczeniach $(88,2 \%)$, teksty do przeczytania $(82,3 \%)$, prace pisemne $(82,3 \%)$ i karty pracy $(64,7 \%)$. Czasami nauczyciele proszą o przygotowanie informacji na określony temat $(23,5 \%)$, pokolorowanie kolorowanki (17,6\%) lub o wykonanie doświadczenia lub obserwacji $(11,7 \%)$. Według przebadanych rodziców nauczyciele najczęściej zadają wybrane zadania z podręcznika lub ćwiczeń $(91,6 \%)$, tekst do przeczytania $(66,6 \%)$, prace pisemne w zeszycie (59,5\%), karty pracy $(39,2 \%)$. Zdecydowanie rzadziej uczniowie mają za zadanie wyszukać informacje na określony temat (14,2\%), wykonać doświadczenie lub obserwację (9,5\%), pokolorować obrazki (8,3\%). Najmniej respondentów zadeklarowało wykonanie lapbooka $(3,6 \%)$, nauczenie się wiersza na pamięć $(2,4 \%)$, przygotowanie prezentacji $(1,2 \%)$ lub projektu $(1,2 \%)$.

Porównanie odpowiedzi uczniów i rodziców na temat rodzaju zadań do wykonania $\mathrm{w}$ domu, przedstawione w poniższej tabeli, wskazuje na niewielkie różnice, z wyjątkiem nauki wiersza na pamięć. Różnica ta wynika prawdopodobnie z faktu, że rodzice nie uznają tej aktywności za pracę domową.

Wykres 2.

Rodzaje zadawanych prac domowych

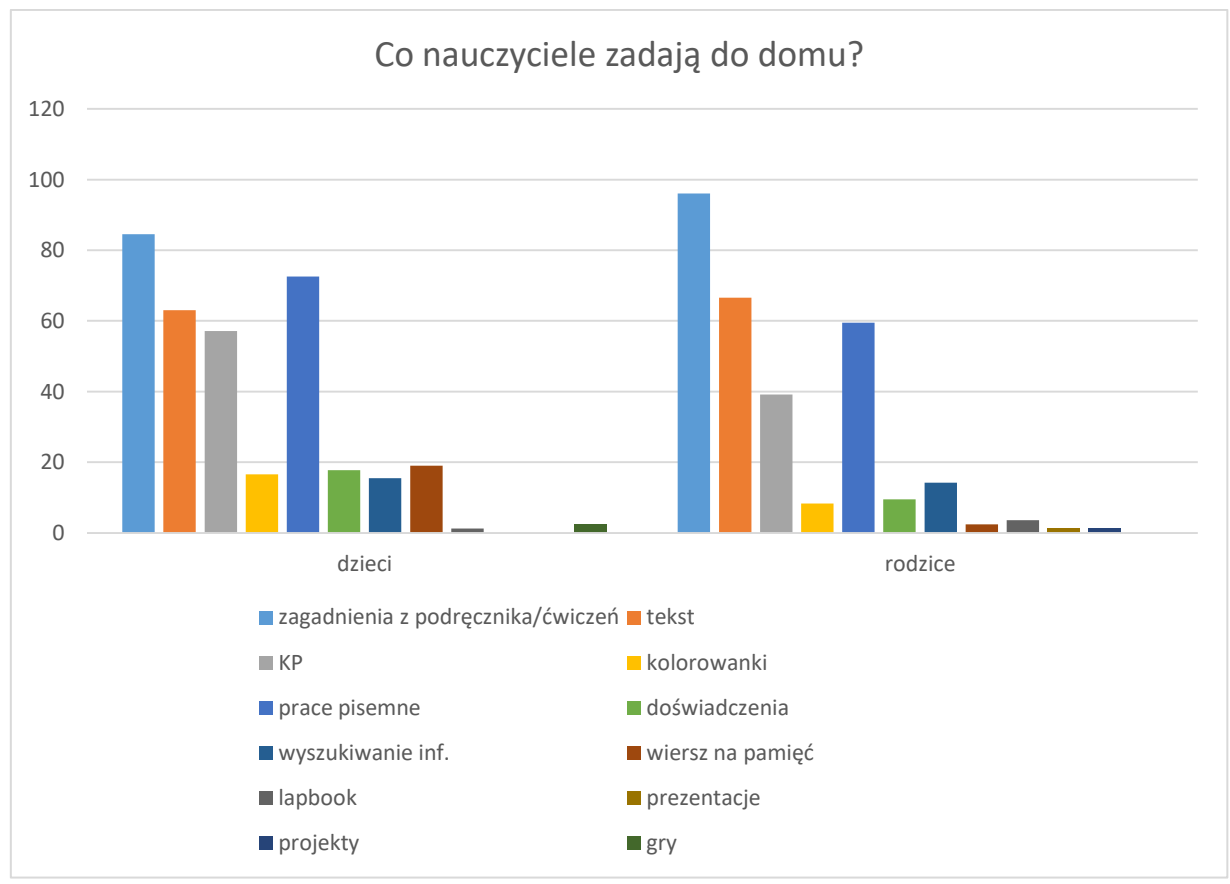


Badaniu podlegał również stosunek uczniów do pracy domowej. Pytanie zadano zarówno uczniom, jak i ich rodzicom.

Wśród badanych uczniów minimalnie przeważa zamiłowanie do prac domowych (46,4\%) nad niechęcią (38\%); 11,9\% badanych jest niezdecydowanych - chęć odrabiania pracy domowej uzależniają od jej rodzaju (30\%). Wśród zwolenników pracy domowej pojawiały się różne uzasadnienia; $23 \%$ uczniów wskazało na zamiłowanie do uczenia się lub wykonywania konkretnych ćwiczeń; 15,3\% uważa, że prace domowe są „fajne i ciekawe”; 12,8\% zwróciło uwagę na fakt uczenia się czegoś nowego; a 7,7\% uważa, że są krótkie i proste; 5,1\% po prostu lubi prace domowe. Pojedyncze odpowiedzi wskazują na motywację zewnętrzną: pochwała od pani, chęć zdobycia lepszych ocen, możliwość wykazania się (po 2,5\%). Kilku respondentów wskazało na to, że praca domowa pozwala lepiej przyswoić wiedzę, motywuje do dalszej pracy lub sprawia im przyjemność (po 2,5\%); 15,3\% zwolenników pracy domowej nie uzasadniło swojej odpowiedzi. Wśród osób deklarujących niechęć do pracy domowej aż 45,1\% uważa, że zabiera ona czas na zabawę; 9,6\% nie lubi się uczyć lub wykonywać konkretnych ćwiczeń. Tyle samo uczniów uważa, że prace domowe są nudne (9,6\%) i że zajmują za dużo czasu (9,6\%). Na zbyt szybkie i niedostateczne tłumaczenie nauczyciela, skutkujące niezrozumieniem zadania zwróciło uwagę $6,4 \% ; 16,1 \%$ nie uzasadniło swojej odpowiedzi. Wśród rodziców panuje przekonanie, że 59,5\% dzieci lubi odrabiać prace domowe (z czego 52\% tej grupy to uczniowie klasy I, 40\% klasy II, a 8\% klasy III). Wśród uczniów nielubiących prac domowych większość stanowią uczniowie klasy II (47\%), 38,2\% tej grupy to uczniowie klasy III, a $8,8 \%$ klasy I.

Niechęć uczniów do odrabiania pracy domowej może wynikać między innymi z czasu, jaki spędzają nad odrabianiem pracy domowej. Aż 23,5\% uczniów, którzy (według rodziców) nie lubią odrabiać pracy domowej, spędza nad nią od godziny do dwóch godzin, a 5,8\% uczniów ponad dwie godziny. To właśnie czas, jaki uczniowie poświęcają odrabianiu pracy domowej, jest najczęstszym powodem sprzeciwu rodziców i dzieci wobec jej zadawania. Według ankietowanych rodziców 27,3\% dzieci spędza do 30 minut nad pracą domową. Największą grupę, bo aż $55,9 \%$, stanowią uczniowie odrabiający pracę domową od 30 do 60 minut; $11,9 \%$ zajmuje to od godziny do dwóch, w skrajnych przypadkach ponad dwie godziny (3,5\%). W klasie I, w której odrabianie pracy domowej nie powinno zajmować więcej niż 30 minut, w tym przedziale mieści się 40,6\% uczniów. Więcej, bo aż 53,1\%, wykonuje pracę domową od 30 do 60 minut. Niepokojące jest, że aż 9,3\% rodziców pierwszoklasistów deklaruje bardzo długi czas, jaki zajmują zadania domowe - od godziny do dwóch (nie wskazując na prace wymagające aż tak długiego czasu na ich wykonanie). W klasie II, gdzie czas może zostać wydłużony, 19,4\% uczniów spędza do 30 minut nad zadaniami domowymi, większość - 55,5\% - od 
30 do 60 minut. Aż 16,6\% badanych mówi o czasie od godziny do dwóch (w tym $16,6 \%$ tej grupy wskazuje na konieczność przygotowywania projektów w domu), a 5,5\% ponad dwie godziny (wskazując jednocześnie na konieczność wykonywania w domu lapbooka lub prezentacji, które są bardzo czasochłonne). W klasie III 18,7\% uczniów spędza do 30 minut nad pracą domową, $62,5 \%$ do godziny, po $6,25 \%$ do dwóch godzin i ponad dwie godziny.

\section{Wykres 3.}

Ilość czasu poświęcanego na odrabianie pracy domowej w poszczególnych klasach

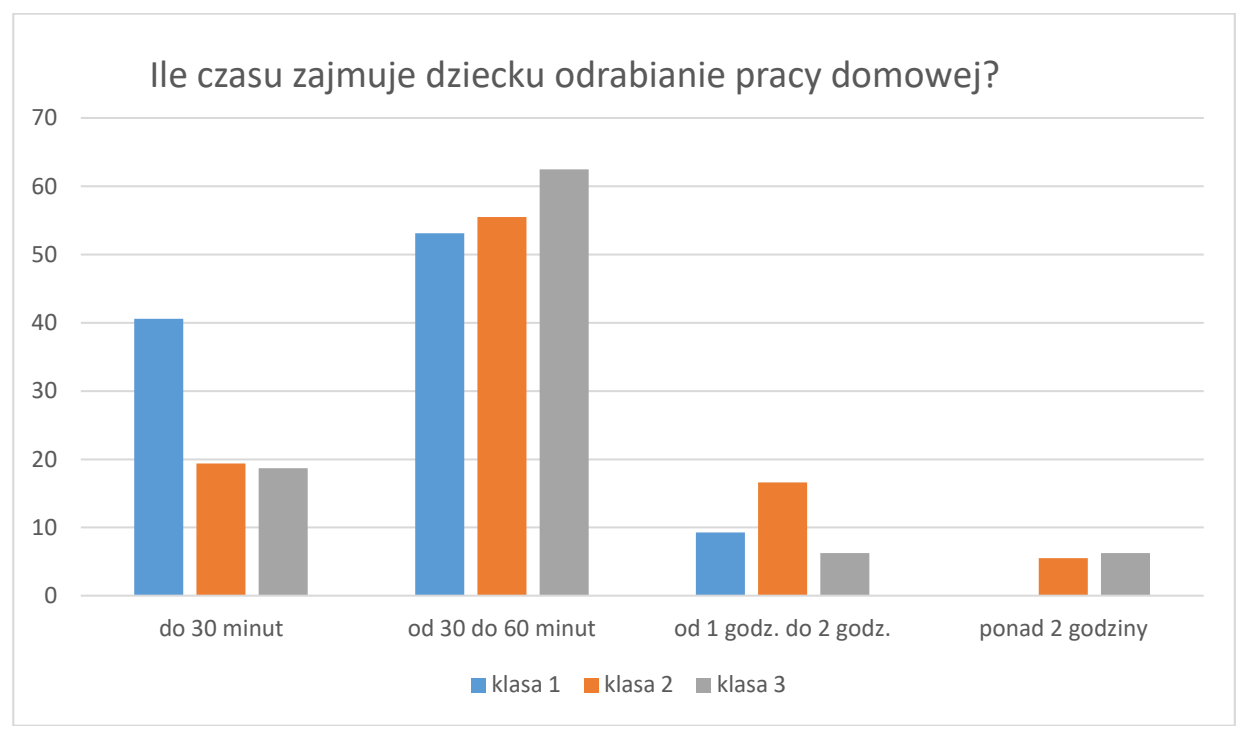

Tylko 7,1\% badanych rodziców twierdzi, że nie pomaga swoim dzieciom w odrabianiu pracy domowej. Pomoc pozostałych respondentów polega na tłumaczeniu polecenia, wyjaśnianiu, co należy zrobić ( $86,2 \%$ tej grupy), pomocy w rozwiązaniu/ napisaniu (17,5\%); 5\% rodziców sprawdza poprawność wykonania zadań; 3,75\% dostarcza dziecku materiały, pomaga w szukaniu informacji w Internecie; 1,25\% pilnuje wykonania zadania w terminie; tyle samo motywuje do wykonania zadania.

Wśród badanych rodziców 73,8\% wskazało na potrzebę zadawania prac domowych głównie ze względu na konieczność utrwalenia materiału $(61,3 \%)$ i doskonalenia umiejętności (12,9\%). Według 12,9\% badanych praca domowa daje też rodzicowi wiedzę dotyczącą postępów dziecka i pozwala na zauważenie ewentualnych problemów oraz uzupełnienie braków $(4,8 \%)$. Respondenci wskazali również ważne cechy dobrej pracy domowej: uczy systematyczności $(16,1 \%)$, obowiązkowości $(12,9 \%)$, 
samodzielności (6,45\%), samodyscypliny (4,8\%), zarządzania czasem $(4,8 \%)$, odpowiedzialności $(3,2 \%)$, pozwala na kreatywność $(3,2)$, rozwijanie pasji $(1,6 \%)$. Rodzice zwrócili także uwagę na motywowanie do dalszej pracy $(1,6 \%)$, wyrabianie nawyku uczenia się (1,6\%), możliwość samodzielnego poszukiwania wiedzy (1,6\%), rozwój $(1,6 \%)$. Wśród zwolenników pracy domowej 3,2\% podkreśliło jej znaczenie w przygotowywaniu uczniów do klasy IV; 1,6\% badanych uznało, że nauka w domu jest tak samo ważna, jak w szkole; 1,6\% stwierdziło, że praca domowa pozwala dokończyć to, czego nauczyciel nie zdążył zrobić na lekcji. Mimo świadomości, jaką rolę odgrywa praca domowa w edukacji wczesnoszkolnej, rodzice zwracają uwagę, że prace domowe są monotonne i nudne. Uważają też, że nie powinny być zadawane codziennie.

Wśród badanych rodziców 23,8\% uznało, że praca domowa na tym szczeblu edukacji nie jest potrzebna; $25 \%$ przeciwników zadawania pracy domowej uważa, że dzieci powinny uczyć się w szkole, a nie w domu; 15\% uważa, że prace domowe nie pozwalają na spędzanie czasu z rodziną; tyle samo respondentów zwraca uwagę na to, że w domu dzieci powinny odpoczywać lub się bawić; 5\% badanych rodziców zwróciło uwagę na formę prac: dzieci mają zrobić w domu to, czego nie zdążyły zrobić w szkole, zadane prace są odtwórcze, demotywują i zniechęcają do szkoły. Według nich praca domowa jest dodatkowym stresem i zabiera czas na rozwój umiejętności dzieci. Odpowiedzi „nie wiem” udzieliło 1,2\% respondentów, uzasadniając ją w następujący sposób: „ze szkoły nie wynosi tyle, ile powinien, ale z drugiej strony brakuje mu czasu dla siebie".

\section{DYSKUSJA WYNIKÓW}

Badania zostały przeprowadzone ze względu na pojawienie się nowych pozycji literackich (Juul, 2014; Hattie, 2015; Kohn, 2018), których autorzy negują konieczność zadawania pracy domowej oraz pojawiających się głosów rodziców wyrażających sprzeciw wobec jej zadawania. Kolejnym czynnikiem był czas, jaki upłynął od przeprowadzenia poprzednich badań (Puślecki, 2005b; Reclik, 2005; Winiarczyk, 2007-2008).

Spośród badanych uczniów 92,7\% przynajmniej raz w tygodniu ma zadawaną pracę domową, co wskazuje na przekonanie nauczycieli o potrzebie zadawania prac domowych. Wyniki badań prowadzonych równolegle wśród 162 nauczycieli edukacji wczesnoszkolnej pokazują, że 95,7\% badanych zadaje uczniom pracę domową (Błażejewska, 2019).

Według badanych uczniów i ich rodziców pośród zadawanych prac domowych dominują wybrane zagadnienia z podręcznika lub ćwiczeń, prace pisemne w zeszycie, tekst do przeczytania i karty pracy. Zdecydowanie rzadziej są zadawane 
wiersze do nauki na pamięć, doświadczenia, kolorowanki lub przygotowywanie informacji na określony temat. Wykonywanie ćwiczeń i kart pracy umożliwia, tak ważne według zasad zawartych w literaturze przedmiotu, utrwalanie wiadomości oraz umiejętności zdobytych przez uczniów podczas lekcji (Zborowski, 1955; Kupisiewicz, 1980; Puślecki, 2005b; Reclik, 2005; Okoń, 2007). Pozostałe propozycje rozwijają, równie istotne, samodzielne myślenie (Kupisiewicz, 1980; Więckowski, 1983; Miodek, 1988; Okoń, 2007). Powyższe wyniki znajdują także odzwierciedlenie w wynikach badań przeprowadzonych wśród nauczycieli edukacji wczesnoszkolnej (Błażejewska, 2019). Według 89,1\% badanych nauczycieli praca domowa ma służyć utrwalaniu wiadomości i doskonaleniu umiejętności, co jest szczególnie ważne przy nauce czytania, pisania oraz liczenia (na to zwróciło uwagę 58,3\% badanych). Dziwi natomiast fakt, że teksty do przeczytania są zadawane w klasie I tylko w przypadku 55\% uczniów. Jest to czas, kiedy przy wprowadzaniu liter czytanka powinna być obowiązkowa i podczas zajęć, i podczas pracy w domu. Czytanie tekstów pozwala utrwalić poznane litery oraz doskonalić umiejętność czytania.

Wśród respondentów 46,4\% chętnie odrabia prace domowe głównie ze względu na zamiłowanie do uczenia się lub wykonywania konkretnych ćwiczeń, możliwość nauczenia się czegoś nowego lub ze względu na charakter prac - są według nich „fajne i ciekawe”, co może wskazywać na związek zadawanych tematów z zainteresowaniami badanych. Uczniowie, którzy nie mogli się zdecydować na jedną odpowiedź (11,9\%), odpowiadali, że „lubią się uczyć lub wykonywać konkretne ćwiczenia”. Według rodziców aż 59,5\% dzieci chętnie odrabia prace domowe. Powyższe dane mogą oznaczać, że część uczniów posiada wewnętrzną motywację do odrabiania prac domowych, nadającą kierunek ich działaniom, a zadawane im, zgodnie z zasadami podawanymi w literaturze przedmiotu (Zborowski, 1955; Reclik, 2005), prace domowe często mają związek z zainteresowaniami badanych. Przeciwnicy pracy domowej zwracają natomiast uwagę na potrzebę odpoczynku i zabawy w domu oraz spędzania czasu z rodziną. Uważają także, że szkoła stara się przełożyć obowiązek uczenia dzieci na nich, a czas, jaki uczniowie poświęcają odrabianiu pracy domowej, jest najczęstszym powodem sprzeciwu rodziców i dzieci wobec jej zadawania.

Czas, który uczniowie poświęcają na odrobienie pracy domowej, w większości przypadków wynosi od 30 do 60 minut (55,9\% uczniów). Duża grupa, bo 27,3\% dzieci, spędza do 30 minut nad pracą domową, jednak aż 11,9\% badanym zajmuje to od godziny do dwóch, a skrajnych przypadkach ponad dwie godziny $(3,5 \%)$. Może to wskazywać na brak indywidualizacji procesu nauczania oraz zadawanych prac domowych, mimo wyraźnych zaleceń zawartych w literaturze przedmiotu (Kupisiewicz, 1980; Więckowski, 1983; Kołodziej, Niesporek-Szamburska, 2009).

Z przeprowadzonych badań wynika także, że ponad $90 \%$ rodziców pomaga swoim dzieciom w odrabianiu pracy domowej, jednak żaden $\mathrm{z}$ nich nie wykonuje 
pracy domowej za dziecko. Pomoc dzieciom polega głównie na tłumaczeniu poleceń i wyjaśnianiu zadań oraz na pomocy w ich rozwiązaniu. Wyniki te nawiązują do wyników badań Anny Winiarczyk z 2004 roku (Winiarczyk, 2007-2008), gdzie rodzice wskazali jako główną przyczynę potrzeby pomocy w odrabianiu lekcji niedostateczne wytłumaczenie pracy domowej przez nauczyciela.

Większość badanych rodziców $(73,8 \%)$ uważa, że praca domowa w edukacji wczesnoszkolnej jest potrzebna. Respondenci uzasadniali potrzebę zadawania prac domowych koniecznością utrwalenia materiału i doskonalenia umiejętności nabytych w szkole. Według nich praca domowa uczy systematyczności, obowiązkowości, samodzielności, samodyscypliny, zarządzania czasem i odpowiedzialności. Prace domowe pozwalają też rodzicom zorientować się, jakie postępy poczyniło ich dziecko lub jakie ma braki. Są to argumenty, które również możemy znaleźć w klasycznej literaturze przedmiotu, gdzie jako cel pracy domowej są podawane: rozszerzanie i utrwalanie wiadomości i umiejętności nabytych w szkole (Zborowski, 1955; Reclik 2005; Okoń 2007), przygotowanie do samodzielnego myślenia (Okoń, 2007; Miodek, 1988), przygotowanie do samokontroli, samooceny (Reclik, 2005) i samokształcenia (Zborowski, 1955; Reclik, 2005; Kołodziej, Niesporek-Szamburska, 2009) oraz uczenie wytrwałości, odwagi i systematyczności (Zborowski, 1955). Podstawową funkcją pracy domowej podkreślaną $\mathrm{w}$ literaturze przedmiotu jest powtarzanie oraz utrwalanie wiedzy i umiejętności (Kupisiewicz, 1980; Więckowski, 1983; Kozak, 1984). Rodzice zwracają uwagę na jakość prac domowych - ich zdaniem powinny być mniej monotonne.

Przeprowadzone wśród uczniów i ich rodziców badania potwierdziły potrzebę zadawania prac domowych podkreślaną w literaturze klasycznej przez Zborowskiego, Kupisiewicza, Puśleckiego, Reclik, Okonia i innych (Zborowski, 1955; Kupisiewicz, 1980; Puślecki, 2005b; Reclik, 2005; Okoń, 2007), głównie ze względu na konieczność utrwalania wiadomości oraz ćwiczenia umiejętności zdobywanych $\mathrm{w}$ szkole, stając w opozycji do zdania autorów najnowszych pozycji literackich (Juul, 2014; Hattie, 2015; Kohn, 2018). Wskazały równocześnie na potrzebę zmiany podejścia do sposobu zadawania pracy domowej oraz jej indywidualizowania (m.in. ze względu na ilość czasu poświęcanego przez dzieci na jej wykonanie).

\section{PODSUMOWANIE}

Ponad 92\% badanych uczniów ma zadawaną pracę domową przynajmniej raz w tygodniu. Częstotliwość ta może świadczyć o docenianiu przez nauczycieli wagi pracy domowej w procesie kształcenia.

Wyniki badań wskazują na pozytywny stosunek badanych do zadawania dzieciom prac domowych, głównie ze względu na konieczność utrwalania wie- 
dzy i doskonalenia umiejętności zdobytych w szkole. Bez systematycznej pracy i ćwiczeń, także w domu, uczniowie mogą mieć problemy w ich opanowaniu. $\mathrm{Na}$ proces kształcenia mają wpływ zadania proponowane uczniom przez nauczycieli do wykonania w domu.

Uczniowie lubiący prace domowe wskazywali głównie motywację wewnętrzną (zamiłowanie do nauki, możliwość nauczenia się czegoś nowego) jako powód pozytywnego stosunku wobec odrabiania prac domowych.

Wśród badanych uczniów 38\% deklaruje niechęć do odrabiania prac domowych spowodowaną głównie chęcią przeznaczenia czasu poświęconego na jej wykonanie na zabawę. Nie dziwi fakt, że czasu przeznaczonego na zabawę jest mało, skoro aż $23,5 \%$ tej grupy spędza nad odrabianiem pracy domowej od godziny do dwóch, a 5,8\% ponad dwie. Ten czas jest zdecydowanie za długi i może świadczyć o braku indywidualizacji bądź niedostatecznym wytłumaczeniu zadań przez nauczyciela. Wskazują na to również odpowiedzi dotyczące pomocy udzielanej dzieciom przez rodziców przy wykonywaniu zadań domowych. Pomoc ta polega głównie na tłumaczeniu poleceń, wyjaśnianiu, co należy zrobić i rozwiązaniu/napisaniu zadania.

Oprócz potrzeby utrwalania wiedzy i doskonalenia umiejętności równie ważne jest rozwijanie uzdolnień i zainteresowań uczniów. Odpowiedzi respondentów wskazują jednak na zbyt częste pomijanie tych obszarów przez nauczycieli podczas planowania prac domowych. Być może wynika to z faktu, że niewielu planuje pracę domową na etapie przygotowywania lekcji. Większość robi to podczas ich trwania (Błażejewska, 2019).

W związku z rolą prac domowych w procesie kształcenia konieczna jest zmiana w podejściu nauczycieli do nich. Zadawane prace domowe powinny częściej rozwijać zainteresowania i pomysłowość uczniów, uczyć praktycznych rzeczy, rozwijać twórczość, uczyć samodoskonalenia, samodyscypliny, samokontroli, samooceny, kształtować umiejętność samodzielnego, krytycznego myślenia oraz być nade wszystko zindywidualizowane.

\section{OGRANICZENIA BADAŃ}

Ze względu na wypełnianie ankiet online większość badanych została dobrana losowo. W przypadku kwestionariuszy ankiet wypełnianych online brakowało kontroli czynników zakłócających, takich jak obecność osób trzecich, włączony telewizor lub inne strony internetowe. Jednak osoby biorące udział w badaniu online robiły to w pełni dobrowolnie. Ze względu na zastosowanie metody sondażu diagnostycznego nie można zakładać, że odpowiedzi badanych wiernie odzwierciedlają ich faktyczne postawy i przemyślenia. Ankiety były krótkie i w pełni anonimowe, co sprzyjało szczerym odpowiedziom. 


\section{LITERATURA}

Adamek, I. (1997). Podstawy edukacji wczesnoszkolnej. Kraków: Impuls.

Bałachowicz, J. (2006). Wczesna edukacja dziecka - problemy teoretyczne i praktyczne. Rola wczesnej edukacji w rozwoju człowieka. W: J. Bałachowicz. A. Kowalska (red.). Wczesna edukacja dziecka. Stan obecny - perspektywy - potrzeby (s. 5-15). Warszawa: Wyd. Wyższej Szkoły Pedagogicznej TWP.

Błażejewska, K. (2019). Praca domowa w opinii nauczycieli edukacji wczesnoszkolnej, artykuł złożony do druku w: Acta Universitatis Nicolai Copernici Pedagogika, XXXVIII, 2/2019.

Błażejewska, K. (2020). Praca domowa uczniów w edukacji wczesnoszkolnej. Forum Pedagogiczne, T. 10, 1, 83-94.

Drozd, E. (1999). Zadawanie do domu. Edukacja i Dialog, 9, 58-63.

Dudel, B. (2007). Praca domowa - krok do samokształcenia w klasie III. W: R. Piwowarski (red.). Dziecko: sukcesy i porażki (s. 156-165). Warszawa: Instytut Badań Edukacyjnych.

Dudzińska, B. (2003). Praca domowa w procesie edukacji. Problemy Opiekuńczo-Wychowawcze, 10, 37-40.

Duraj-Nowakowa, K. (1998). Integrowanie edukacji wczesnoszkolnej. Modernizacja teorii i praktyki. Kraków: Impuls.

Harmin, M. (2005). Duch klasy. Jak motywować uczniów do nauki? Warszawa: CEO Civitas.

Hattie, J. (2015). Widoczne uczenie się nauczycieli. Jak maksymalizować siłę oddziaływania na uczenie się. Warszawa: Biblioteka Szkoły Uczącej się.

Juul, J. (2014). Kryzys szkoły. Podkowa Leśna: Wyd. MiND.

Kohn, A. (2018). Mit pracy domowej. Podkowa Leśna: Wyd. MiND.

Kołodziej, A., Niesporek-Szamburska, B. (2009). Konteksty i uwarunkowania zadań domowych. II część cyklu: O pracach domowych z języka polskiego prawie wszystko. Kielce: Wyd. Pedagogiczne ZNP.

Kozak, H. (1984). Organizacja pracy domowej uczniów klas początkowych. Warszawa: Instytut Wydawniczy Związków Zawodowych.

Kujawiński, J. (1990). O nową jakość pracy lekcyjno-domowej. Życie szkoły, 1, 13-20. Kupisiewicz, C. (1980). Podstawy dydaktyki ogólnej. Warszawa: PWN.

Kupisiewicz, C., Kupisiewicz, M. (2009). Słownik pedagogiczny. Warszawa: PWN.

Lulek, B. (2017). Rodzice obecni - nieobecni w edukacji szkolnej dziecka? W: A. Domagała-Kręcioch. B. Majerek (red.). Kategorie (nie)obecne w edukacji (s. 217-229). Kraków: Impuls.

Miodek, E. (1988). O problemach pracy domowej ucznia klas I-III. Chowanna, 1, 48-54. Niemierko, B. (2014). Uczeń odrabia pracę domową. Nowa szkoła, 2, 29-30. 
Nowik, J. (2013). Kształcenie matematyczne w edukacji wczesnoszkolnej. Opole: Nowik. Okoń, W. (2007). Nowy słownik pedagogiczny. Warszawa: PWN.

Okoń, W. (2003). Wprowadzenie do dydaktyki ogólnej. Warszawa: Żak.

Puślecki, W. (2005a). Praca domowa ucznia. W: T. Pilch (red.). Encyklopedia pedagogiczna XXI wieku, t. IV (s. 788-799). Warszawa: Żak.

Puślecki, W. (2005b). Praca domowa najmłodszych uczniów. Kraków: Impuls.

Reclik, R. (2005). Rola i miejsce pracy domowej w kształceniu zintegrowanym. W: Z. Ratajek (red.). Uczeń we współczesnej szkole. Problemy reformy edukacji wczesnoszkolnej (s. 137-141). Kielce: Wyd. Akademii Świętokrzyskiej.

Reclik, R. (2007). Praca domowa uczniów w młodszym wieku szkolnym między teorią a praktyką. W: H. Siwek (red.). Efektywność kształcenia zintegrowanego. Implikacje dla teorii i praktyki (s. 158-163). Katowice, Warszawa: Wyd. Wyższej Szkoły Pedagogicznej TWP.

Więckowski, R. (1983). Nauka domowa dziecka w młodszym wieku szkolnym. Życie szkoły, 3, 164.

Winiarczyk, A. (2007-2008). Praca domowa uczniów klas początkowych w opinii rodziców. Nauczanie początkowe, 2, 60-67.

Wujek, T. (1969). Praca domowa i czynny wypoczynek ucznia. Warszawa: PZWS.

Zborowski, J. (1955). Praca domowa ucznia szkoły podstawowej. Warszawa: PZWS.

\title{
STUDENTS’ OF EARLY SCHOOL EDUCATION AND THEIR PARENTS' OPINIONS
}

\section{ON HOMEWORK}

\begin{abstract}
Introduction: This article is about homework in early school education. Purpose and method: A review of the pedagogical literature has been carried out. Diagnostic survey research was carried out among 84 students of early school education and theirs parents, focusing on their opinion on homework, in particular: the declared frequency of assigning homework, types of homework, students' attitude to homework and amount of time spent on doing it. Results: $98.8 \%$ of pupils surveyed have homework. Among the homework asked, selected topics from the manual or exercises, written works in the notebook, text to read, work cards, learning poems by heart, experiments, coloring pages and preparing information on a specific topic prevail. The most common reason parents and children object against asking homework is the time pupils spend doing it. The subjects pointed out the need to ask homework mainly due to the need to fix the learning material and to improve skills. Conclusions: Research indicates the need to ask homework mainly because of necessity of consolidating knowledge acquired at school and of improving pupils' skills.
\end{abstract}

Keywords: early school education, homework, parents, students 